\title{
FANTASMAS DA LIBERDADE: A RELAÇÃO ENTRE TEORIA E PRÁTICA COMO CRÍTICA ÀS FORMAS DE RECONCILIAÇÃO ENTRE ESPÍRITO E NATUREZA
}

Ghosts of freedom: the relationship between theory and practice as critical the forms of reconciliation between spirit and nature.

Fantasmas de la libertad: la relación entre teoría y práctica como crítica las formas de reconciliación entre el espíritu y naturaleza

\section{Resumo}

Neste artigo, o autor recompõe uma passagem da Dialética Negativa, de Adorno, com a intenção de desenvolver um modelo de pensamento a partir do qual a ideia de liberdade é relacionada ao problema teoria-prática.

Palavras-chave: Liberdade. Teoria. Prática. Adorno.

\section{Abstract}

In this paper, the author reframes a passage in Adorno's Negative dialectics, with the intent of developing a thought model by which the idea of liberty is related to the theory-praxis problem. Keywords: Liberty. Theory. Praxis. Adorno.

\footnotetext{
Doutor em Folosofia. Professor do Departamento de Filosofia da UFMG.ORCID: https:// orcid.org/0000-0002-8601-7617. E-mail: eduardosns@ufmg.br.
} 


\section{Resumen}

En este artículo, el autor posiciona un pasaje de la Dialéctica negativa, de Adorno, con la intención de desarrollar un modelo de pensamiento en que la idea de libertad esté relacionada con el problema teoría-práctica.

Palabras clave: Libertad. Teoría. Práxis. Adorno.

Efemérides, a que servem? 114 anos do nascimento de Adorno. Celebração, memória, atualização? Sob esses marcos mais salientes de atribuição de sentido à passagem de anos, pesando sobre uma obra do mesmo modo que pesa sobre cada qual, tanto indício de sua significação contingente como de seu iminente retorno ao insignificante, sob esses e tantos mais marcos vige um incômodo. O que estamos fazendo, exatamente? Não apenas conosco, mas, agora, com essa obra? Ao lado da docilidade da reverência, que secreta o mel da inclusão de si mesmo em uma narrativa de combate à barbárie, um tipo autocomplacente, portanto, um "eu tentei!" bradado aos ventos - caso contrário, por que seríamos reverentes a uma obra que se define como momentânea tentativa de ordenação? -, ao lado da reverência parece haver outros tipos, o do scholar ou historiador, a quem o risco da esterilização - justamente de uma obra que contra isso reage - é função estrita do domínio do métier, e também o tipo que persevera, em crônico furor, no diagnóstico de tempo, a quem aparentemente cabe, quase por antonomásia, a tarefa da crítica - que isso se faça a partir de conceitos e categorias muito específicos é o dado que não impede o incômodo. Volto a isso, sim, volto, porque há 11 anos me movimentei entre esses tipos ao escrever sobre a categoria de constelação em Adorno $^{2}$ e retirei uma ideia que só agora começa a aparecer, para mim, no plano de suas consequências.

O que implica escrever sobre Adorno? Mais especificamente, sobre a Dialética Negativa? Notem que não estou perguntando o que é ela, mas o

2 Cf. Silva (2006). Para uma síntese do argumento, Cf. Silva (2009). 
que implica escrever sobre ela. À época, já velho de muitas luas, mas ainda não marcado pela urgência, conclui que a leitura da obra de Adorno deveria se guiar pelo que chamei de análise modelar, ou análise de modelos, marcada por uma compreensão detida da categoria de constelação, categoria entendida como: princípio de composição, procedimento metódico e modo de ser do pensamento enquanto correlato ao modo de ser da coisa. Tal ideia permanece, em grande medida, basilar na minha labuta. Porém, ainda que a noção de análise de modelos assim o exija e que a própria tese faça exatamente isso, o que estava em questão ainda não era como escrever sobre Adorno, mas como ler sua obra. Se fôssemos refletir, pois, sobre os modos de escrita, aqueles que a tradição interpretativa efetivamente realiza, reencontraríamos derivações daqueles tipos anteriores, não por acaso articulados aos modos da constelação. Todos esses tipos, não de leituras, mas de escritas, são variações miméticas: do estilo, das tópicas, da forma de conceituar e argumentar, do modo de caracterização dos problemas. Quem escreve sobre Adorno, obviamente, reconhece, recua e busca esses limites em sua própria escrita, mais do que isso, como entes reais, nós somos sempre um excesso ao que diz um tipo - o que não implica que esses tipos, ideais, percam sua capacidade de gerar juízos de atribuição de sentido às singularidades não recorrentes, em virtude de sua possibilidade objetiva, como dizia Weber, e sabia Adorno. De todo modo, o caso é que a dificuldade específica de escrever sobre Adorno, da qual eu já suspeitava, só se tornou questão filosófica no momento em que eu tornei-me professor e, a fortiori, escritor por ofício. O que se segue, porque tudo até aqui foi um introito provavelmente maior do que deveria ser, pelo que já me desculpo, é o esforço de responder a uma questão que então me escapava: como escrever sobre Adorno, como intérprete de seu pensamento e, nessa medida, como adorniano? Não se trata da questão sobre como interpretar, em geral, ou mesmo interpretar Adorno, mas uma questão muito mais específica: como permitir que uma pessoa, ao ler o que eu escrevo sobre Adorno ou ouvir o que falo porque escrevo sobre Adorno, compreenda-o para além do mimético, para além da reiteração ad nauseam do conteúdo de seu pensamento ou a assimilação acrítica de seu 
estilo? Pela omissão, já se nota que minha resposta parte de uma posição: ao escrever sobre Adorno, sua filosofia deve aparecer, sobretudo, como uma forma de colocar problemas, um jeito de lidar com conceitos e argumentos. Chamem-na de crítico-materialista, de dialética negativa, de teoria crítica, como quiserem. Para todos os efeitos, isso tem nome na obra de Adorno: modelo de pensamento.

Para os propósitos deste texto, tomarei um tema central da obra tardia de Adorno, que envolve a relação entre materialismo e moral, para, por assim dizer, realizar a genealogia de uma passagem incompreensível por si mesma na Dialética Negativa. O tema que escolhi é o da liberdade e a passagem é a seguinte:

O fantasma da liberdade - que não deixa a razão se estiolar em face da presença de nenhuma prova de interdependência causal - é o fantasma de uma reconciliação entre espírito e natureza (ADORNO, 2009, p. 193).

Entendo que a leitura dessa passagem, como dito, deve partir da análise do modelo de pensamento no qual ela já se inscreve. Se a tarefa é a de interpretação, então cumpre recompor a interpretação que Adorno faz aí, das posições de Kant e Hegel, diretamente implicados, bem como remontar a passagem à figura da reconciliação com a natureza como problema, ou seja, ao materialismo em geral, a Marx em particular. Todavia, escrever sobre isso, fazer uma exegese que não caia nem na celebração, nem na estilização, não é o mesmo que colocar, como intérprete, a filosofia de Adorno em movimento, ou seja, não é pensar junto a Adorno, mas ainda pensar dentro dele. Dado que seu pensamento, justamente, veta a mera reiteração, ainda que explicada em pormenor, de uma dada apresentação dos problemas, em face do cerne temporal da verdade, da impermanência dos diagnósticos, em suma, da contingência, fazer tal interpretação é, ainda, a esterilização do seu pensamento pela assunção de seu conteúdo. Logo, uma leitura da passagem que seja a análise do modelo de pensamento em jogo, embora perfeitamente adequada ao contexto formativo, fica aquém 
do desiderato da crítica imanente e, portanto, apartada da verdade em sentido enfático. Por isso, escrever sobre a passagem, junto a Adorno, implica outro procedimento: não a análise modelar, modo adequado de leitura, mas a composição de modelos de pensamento, modo crítico de escrita.

A proposta que faço é: abordar a figura-chave na passagem em questão, fantasma da liberdade, a partir de outra constelação de textos, problemas, conceitos e argumentos, a partir de outro modelo de pensamento, a saber, a relação entre teoria e prática. Pensar, junto a Adorno, a figura do fantasma da liberdade em Kant, Hegel e Marx, de modo a não apenas ler a passagem, interpretá-la, mas também escrever a partir dela, pensar criticamente, leva a uma pergunta que não está ali colocada: será que o fantasma da liberdade, o fantasma de uma reconciliação entre espírito e natureza, poderia ser capturado como um problema na relação entre teoria e prática? O que aventarei é que em cada uma das imagens de reconciliação postas por esses três autores, Kant, Hegel e Marx, oculta-se um fantasma, uma indigitada limitação no conceito de liberdade, em função da relação entre teoria e prática pressuposta em cada caso, o que implica, em caráter singular, pensar a revolução.

O primeiro momento é kantiano. Trata-se de perguntar como ele concebe a relação entre teoria e prática. O ponto de entrada escolhido é o opúsculo "Sobre a expressão corrente: Isto pode ser correto na teoria, mas nada vale na prática", publicado no periódico Berlinischen Monatsschrift, em $1793^{3}$. A tese implícita é que este texto, não outro, inaugura o problema teoria e prática, na forma a partir da qual ainda hoje pensamos.

\section{Primeiro momento: Kant, sobre a expressão corrente (Gemeinspruch)}

Comecemos com destacar, no texto, duas definições gerais, articuladas entre si: regras práticas são teoria, quando pensadas como princípios

3 O texto de Kant, Über den Gemeinspruch: Das mag in der Theorie richtig sein, taugt aber nicht für die Praxis, será doravante referido por Gemeinspruch, seguido da numeração na edição alemã. 
com escopo universal; e prática é a realização de um fim, como execução de princípios procedimentais gerais.

A mediação entre ambas se dá pela faculdade de julgar: a ela cabe examinar se o ato (prático), é caso da regra (teórica). O primeiro grupo de argumentos apresentados por Kant se refere extensivamente à relação entre teoria e prática científicas, o que traz à baila o (muitas vezes esquecido) passado kantiano: professor de filosofia da natureza, física, em uma palavra; nesse caso, a saber, o de teoria e prática que dizem respeito a objetos da experiência, não há força alguma na expressão corrente, pois é tacitamente impossível que teoria e prática se contradigam. Em consequência, a transição e o problema colocados se referem apenas à relação entre teoria e prática no campo do dever: dado que seus objetos se referem a objetos da intuição (Kant ressalta que o mesmo ocorreria com objetos exclusivamente pensados segundo conceitos), é ao menos possível que eles sejam ou vazios ou cegos ${ }^{4}$.

Depois de demarcado o campo - deveres de virtude e deveres de direito, referentes ao campo privado e político (esse, no estado ou no mundo) - Kant anuncia a divisão e propósitos do texto, notando algo crucial para nossa questão: em termos de razão prática, o valor da prática ela mesma está integralmente condicionado a sua conformidade à teoria (Gemeinspruch, A204), pois a própria relação entre regras, princípios e fins se esvairia caso as condições (contingentes) da prática viessem a dar forma à lei (necessária).

Com isso, inaugura-se, largamente, o problema teoria-prática: cabe à razão prática a tarefa de conformar o plano de contingência, portanto, o dever de realizar - no caso da faculdade de juízo, o de avaliar - um ato necessário, ou seja, um ato conforme a ideia mesma da razão prática: se ela tem o poder de criar regras e princípios morais, ela também tem o poder de impô-los a si.

\footnotetext{
4 Como é claro, Kant está, lateralmente, se referindo a uma tópica da primeira Crítica: Gedanken ohne Inhalt sind leer, Anschauungen ohne Begriffe sind blind ("Pensamentos sem conteúdo são vazios, intuições sem conceitos são cegas"). Doravante, a Crítica da razão pura será referida por $K r V$, seguido da numeração na edição alemã, bem como a data e paginação da edição em português. Neste caso: $K r V$, (B75, A51) (1987, p. 55).
} 
Ora, toda a discussão em "Sobre a expressão corrente" encaminha-se para o seguinte ponto: uma eventual legislação, ou seja, um conjunto de deveres de virtude e deveres de direito (Gemeinspruch, A206) que siga um princípio de validade universal e necessária não determina os fenômenos práticos, ele deve determiná-los. Trata-se de um interesse da razão. Retomando um ponto da $\operatorname{KrV}(B 575, A 547)(1988$, p. 107), se a razão prática se define pela capacidade de agir segundo imperativos, então uma prática plenamente adequada à razão teórica exige imperativos categóricos. Em consonância a isso, inaugura-se a polêmica acerca do fato da razão (BECK, 1961).

Nesse sentido, a questão teoria-prática em Kant segue uma intuição já presente na $\operatorname{KrV}($ B373, A316) (1988, p. 17), a de que uma constituição de máxima liberdade é uma ideia necessária e tem que ser posta como fundamento de toda constituição política e de todas as leis. Em resumo, a fundamentação do direito e do estado coincide formalmente com a resolução do problema teoria-prática em termos de deveres de virtude. A mesma razão que prescreve o fim da guerra não porque ela cause dor, mas porque isso é condição de efetivação do direito racional, é a razão que prescreve o imperativo categórico como recurso da prática. $O$ direito é a forma racional da relação entre seres livres, que encontram no imperativo categórico o modo análogo de avaliação da conformidade da prática à teoria, ou ainda, da adequação entre regras, princípios e fins para a ação. Dito de outro modo, a filosofia prática de Kant é uma investigação das condições de possibilidade de uma prática racional, ou seja, uma situação meramente possível na qual todas as ações de um indivíduo se conformem à totalidade das ações livres dos outros (ROHDEN, 1981, p. 54). Tal situação coincide, para Kant, com a ideia racional de um estado de direito.

Com isso, a relação entre teoria e prática, no bojo de uma filosofia da história orientada para (não a partir de) uma ideia, está intrinsecamente marcada por uma filosofia do direito e do estado. A partir daí, como o texto indica, Kant restabelece o problema do contrato, com algumas consequências importantes. 
Note-se que o contrato social, originário, no texto de Kant, é uma ideia da razão pura prática, a priori, independente de toda experiência, ele é uma ideia reguladora mesmo que jamais tenha existido (BOBBIO, 1984, p. 127), mais do que isso, ele é um princípio crítico de todo estado. Analogamente, também o estado de natureza é uma ideia da razão. A contraposição entre esses, todavia, reconfigura um problema clássico da filosofia política, especificamente, da teoria e da prática política, a saber, o direito de resistência. Por um lado, o estado de direito, como comunidade racional de liberdade externa (HÖFFE, 2005, p. 255), é o único capaz de efetivar as condições sob as quais o interesse da razão se realiza; por outro lado, exatamente porque seus princípios, para serem válidos, devem implicar a capacidade de adesão universal, mas essa, por sua vez, implica o dever de conformação aos princípios por parte dos indivíduos, tal adesão não é garantida. Com isso, pode não haver, empiricamente, coincidência entre os atos do estado e a vontade do todo. A esse problema, Hobbes, e o contratualismo de matiz jusnaturalista na sequência, responde a partir da afirmação de direitos inalienáveis, cuja violação é entendida como injustiça. Abre-se, assim, a porta da resistência.

Entretanto, mesmo seguindo Hobbes no reconhecimento do problema, Kant não concluirá pelo direito positivo, ativo, de resistência. Por duas razões: a vontade geral não deve ser entendida de modo empírico, pois essa, o mero somatório de vontades individuais está marcado por interesses, erros de juízo, erros de aplicação do imperativo etc.; associado a isso, o direito tem caráter estatal, por isso sua rejeição, mesmo que motivada, estaria guiada não pela ideia de contrato social, mas pelo seu contrário: quem insiste nisso, na defesa do direito inalienável pela força, está guiado por outra ideia, a de estado de natureza. A destruição do soberano, conservador do regime legal do estado de direito, coincidiria com a destruição do estado e o retorno ao estado de natureza (TERRA, 2003, p. 115). Dito de outro modo, Kant entende que o desejo de revolução se baseia na assunção de que houve de fato, em algum momento, um contrato originário que foi usurpado pelo soberano e que, por via 
da revolução, será recuperado (ZINGANO, 1989, p. 281). Sucintamente, poderíamos dizer que o ideal revolucionário é um erro categorial: toma-se um juízo de possibilidade como se fosse um juízo de existência. Por certo, Kant não pode concordar com nada disso.

O que resta, então, do problema teoria-prática, em termos especificamente políticos, a partir dessas considerações? Se como vimos, os deveres de virtude estão formalmente limitados pelos deveres de direito, então o que fazer, em uma situação de ofensa aos direitos inalienáveis por parte do estado, já que uma resistência ativa destruiria a constituição legal do estado, ele mesmo condição racional de efetivação da relação de liberdade?

Kant responde com clareza, embora não sem consequências imprevistas, justamente o que teceu o liame de parte do criticismo a partir de então. Não se trata, de modo algum, de defender um estado autoritário e, ao mesmo tempo, elogiar a revolução francesa, como muitos de seus primeiros intérpretes contestaram. Ao contrário, Kant estabelece um contorno possível para a resistência, composta por dois elementos (Gemeinspruch, A265-267): a possibilidade, que deve ser garantida a todo cidadão, de criticar publicamente, na forma da "liberdade de escrever", qualquer ato jurídico do soberano; e um direito de resistência negativo ${ }^{5}$, que se faz a partir dos representantes no parlamento, de recusar os atos de governo, em nome do direito do estado (HÖFFE, 2005, p. 258). Tratase, pois, no caso da revolução francesa, de um elogio oblíquo: não por seu ato, mas por seu resultado instituído.

Impossível, porém, deixar de reconhecer que se a solução kantiana não nos condena à inação, condena a uma espécie de expiação legal. O motivo, para retornar à passagem de Adorno em foco, não é outro que o "fantasma da liberdade". No interior de uma filosofia da história formalista, Kant não é capaz de encontrar a fonte fática da liberdade e, portanto, é levado a ter que defender o ideal do estado de direito contra o fato do estado

5 A expressão aparece em uma passagem correlata, na Rechtslehre: §49 A181, B211. 
de direito, o ideal da resistência contra o fato da resistência. Entende-se que Kant não queira dar esse passo, dado que a saída possível parece ser dobrar-se ao particular, ao empírico, recuar para aquém da crítica. Não é preciso, porém, ser pré-crítico para colocar a questão que importa: de onde vem - em termos formais - a ideia de liberdade que emana de cada bloco do edifício do estado de direito visado? Ao contrário do que Kant propõe, ela não vem do contrato originário como ideia reguladora. A representação da liberdade, não de seu fantasma, é função da sociedade de troca. A troca é condição de possibilidade da ideia de autonomia na qual se reverte a ideia de liberdade, no estado de direito burguês.

Eis aí o primeiro fantasma da liberdade, aludido na passagem de Adorno, a partir do qual se abre a contraposição hegeliana ao problema. Trata-se, agora, de perguntar como Hegel concebe o problema teoria e prática a partir do desvelar do fantasma de liberdade que animava a filosofia kantiana. Farei isso a partir das "Linhas fundamentais da filosofia do direito ou direito natural e ciência do estado em compêndio", de $1820^{6}$.

\section{Segundo momento: Hegel, linhas fundamentais (Grundlinien)}

De imediato, se atentássemos para uma disposição primária da filosofia de Hegel e fizéssemos a pergunta pela relação teoria e prática, teríamos forçosamente que dizer que aquela, se tomada segundo seu conceito, tem em si essa última7. Como já indica a primeira nota ao texto, o verdadeiro conceito dá a si mesmo sua efetividade; mais do que isso, a forma concreta, o ser-aí ao qual se chega pela efetivação do conceito, é seu outro essencial.

\footnotetext{
6 O texto de Hegel, Grundlinien der Philosophie des Rechts oder Naturrecht und Staatswissenschaft im Grundrisse, será doravante referido por Grundlinien, seguido do número do parágrafo na edição alemã.

7 Mais do que a conclusão, esse é o ponto de convergência preliminar dos dois estudos mais importantes acerca da relação entre teoria e prática em Hegel, os de Treptow (1971) e Riedel (1976).
} 
Logo, segundo o conhecimento de seu próprio conceito, na unidade da ideia, isto é, na unidade do conceito e do ser-aí, teoria é prática.

Entretanto, para atar com a questão com a qual fechamos a discussão sobre Kant, a pergunta correta é: como conceber a liberdade, ou a prática política da liberdade, no estado de direito? Há aqui dois aspectos que remetem um ao outro, ambos no contraste com Kant: o primeiro diz respeito à noção de liberdade em Hegel, o segundo, a sua concepção do direito e estado. Comecemos pela primeira.

Hegel toma como dado crítico em sua consideração da posição kantiana um aspecto que talvez pudesse ser melhor indicado em um texto de Kant um pouco posterior ao Sobre a expressão corrente, voltado justamente ao direito: Primeiros princípios metafísicos da doutrina do direito ${ }^{8}$, primeira parte da Metafísica dos costumes. Ali, ao retomar as noções de liberdade negativa - a mera independência em relação a princípios que determinem a ação - e de liberdade positiva - a possibilidade da razão pura ser prática por si mesma, a de condicionar a ação por uma lei da razão -, Kant inicia pela consideração da liberdade negativa, passa por um conceito de liberdade como autonomia, de derivação rousseauniana, e conclui pela noção de liberdade positiva, que faz da autonomia a ideia pura da razão em pauta ${ }^{9}$. A consideração da relação entre estado e liberdade, a partir dessa posição do problema, leva Kant a concluir que: i) a autonomia do estado, segundo as leis da liberdade, é garantida pelo exercício dos três poderes e ii) sua felicidade, a felicidade do estado, entenda-se, consiste na união desses poderes, condição na qual a constituição se conforma aos princípios do direito (Rechstlehre, §49). Ao retirar as consequências imediatas dessa consideração, além de reafirmar, em passagem muito

8 O texto de Kant, Metaphysischen Anfangsgründe der Rechtslehre, de 1797, será doravante referido por Rechtslehre, seguido do número do parágrafo na edição alemã.

9 Note-se, desde já, que essa passagem do texto kantiano é tratada criticamente por Hegel neste "Linhas fundamentais da filosofia do direito ou direito natural e ciência do estado em compêndio" (Grundlinien, §29). Para os demais aspectos dessa crítica à noção kantiana de liberdade, cf. Geiger (2007, passim). 
citada, que a felicidade do estado não coincide com a felicidade ou o bem-estar dos cidadãos, até porque isso ocorreria mais facilmente em um estado de natureza, Kant afirmará que contra o supremo legislador não pode haver oposição legítima por parte de qualquer súdito.

Ora, por um lado isso apenas reitera o que já havia indicado, a limitação formal dos deveres de virtude pelos deveres de direito, o que impede a resistência ativa em caso da ofensa aos direitos inalienáveis por parte do estado. Por outro lado, e é esse o foco da crítica de Hegel, toda a argumentação kantiana, especialmente ao considerar a relação entre direito e liberdade, está voltada a um passo instituinte, ou ainda, a um dever ser que se estende desde o campo formal da constituição até o campo da vontade, na forma do imperativo. Se retomarmos uma questão apenas mencionada na seção anterior, encontraríamos a seguinte justificativa: o fato do ser humano já ser membro de um mundo inteligível em virtude da razão teórica não implica que estejam assegurados os princípios da razão prática; dito de outro modo, a consciência da espontaneidade da razão não implica, espontaneamente, a consciência da lei moral. Logo, concluirá Kant, não é possível esperar uma dedução do princípio moral a partir da prova da liberdade da vontade (ALMEIDA, 2009, p. 37). Isso não apenas isso leva Kant a apostar no fato da razão, o que acarreta uma polêmica específica (se não há dedução do princípio moral, trata-se, então de recaída no dogmatismo?) ${ }^{10}$, como também reconfigura a empreitada da razão prática kantiana em torno da premência da efetivação do direito racional em um ideal de estado, um estado de direito por vir.

Aqui retorna, então, o problema inicial apresentado por Hegel no texto em foco, bem como a consideração de Adorno acerca do fantasma da liberdade: a questão mesma do fato da razão nada mais é que a explicitação do caráter meramente formal da concepção kantiana de liberdade, estado e direito, Hegel diria, essas determinações abstratas do

10 Cf. Beck (1961) e, para os propósitos desse argumento, Almeida (2009, p. 44). 
entendimento. Dito de outro modo, o limite dessa concepção kantiana é função de seu formalismo, seu caráter abstrato (Grundlinien, §30). A contraposição é estrita: já no Prefácio de Linhas fundamentais (Grundlinien, $X X I$ ), afirma-se que o estado deve ser entendido como coisa racional em si, efetividade já posta. Hegel, com isso, quer notar que, em sua efetividade, o estado já é racional, mais do que isso, ele é o universo ético que define a objetividade, verdade e eticidade dos próprios indivíduos (Grundlinien, §258). Todos os projetos individuais de objetivação já têm seu lugar no interior do estado de direito. Retomando o ponto inicial, o verdadeiro conceito de estado, direito e liberdade deu a si mesmo sua efetividade, sua forma concreta: esta. A pergunta correta a se fazer, portanto, é acerca da relação da liberdade e do direito com essa forma concreta, o estado.

Não sem antes notar uma ambiguidade no uso do termo "direito" por Hegel, ora referente a uma parte do sistema, ora referente a todo o sistema, cumpre indicar que sua concepção é, em uma sentença, uma rejeição in totum de duas imagens que acompanham a problemática do estado desde o início da filosofia moderna, no mais das vezes quase literalmente ou, no caso de Kant, a partir do recurso ao expediente "ideia da razão"; são elas: estado de natureza e contrato social. Se quiserem, uma rejeição do jusnaturalismo - à parte o fato de que, como ressalta Bobbio (1989, p. 93), Hegel é simultaneamente seu carrasco e executor. Em vez de examinar como ele as rejeita, pois o faz literalmente, convém examinar como Hegel demonstra que ambas são abstrações advindas de uma compreensão parcial do problema da liberdade.

Ainda em Linhas fundamentais, Hegel afirma: o direito é, "em princípio, a liberdade enquanto ideia" (Grundlinien, §29). Conclusão de um longo percurso argumentativo que resulta da sucessão das figuras da vontade, tal posição do direito é o final da série de suprassunções operadas pela vontade livre em si e para si. O direito aparece como correlato da autoconsciência que se apreende enquanto essência da liberdade e, assim, se desfaz de toda liberdade contingente (Grundlinien, §21), o que dá a forma final à tese de que "o sistema do direito é reino da liberdade efe- 
tivada, o mundo do espírito produzido a partir do próprio espírito como uma segunda natureza" (Grundlinien, §4). Se forçássemos Hegel a falar, nessa passagem, de modo mais direto, teríamos o seguinte. Devem ser distinguidas três figuras ou formas da liberdade, cada qual suprassunção da que Ihe antecede: a liberdade em face do estado, a liberdade no estado e liberdade do estado (BOBBIO, 1989, p. 86-89), cada qual com seu momento, sua figura própria.

A primeira delas, liberdade em face do estado, é a forma jurídica do direito abstrato, liberdade externa, negativa, ou seja, condição de liberdade entendida como o resultado da colimitação das liberdades. Para Hegel, essa é a figura à qual Kant inevitavelmente retorna, um lastro hobbesiano, o fantasma do qual ele quer se livrar. Trata-se de uma liberdade que tem caráter de prescrição negativa, na forma: esse é um limite, portanto não faça isso. As duas imagens jusnaturalistas que se tornam ideias da razão em Kant, estado de natureza e contrato social, formam o limiar dessa figura. Obviamente, Kant pretende, inclusive por seu equacionamento da questão a partir de ideias da razão, fundamentar aquela que, conforme Hegel, é ainda apenas a segunda figura da liberdade, ainda um fantasma: a liberdade no estado, forma jurídica da liberdade na sociedade civil. A referência aqui, tanto de Hegel como também de Kant, é Rousseau: trata-se da liberdade que cada cidadão realiza por ser um cidadão submetido às leis. Sendo liberdade da sociedade civil, consiste em uma obediência às leis soberanas, quaisquer que sejam, dado que elas instituem a condição formal da relação de liberdade. O que faz Hegel, na sequência, é identificar e separar o que, segundo sua argumentação, desde os jusnaturalistas até Kant, esteve sempre unido significando o mesmo: sociedade civil e estado. A liberdade do estado, portanto, se realiza após a sociedade civil, no estado que tem sua forma jurídica na constituição. Esse é o momento presente, forma concreta, a efetivação do conceito de liberdade. Não se trata de mero giro terminológico, por duas razões, mutuamente implicadas.

Em primeiro lugar, o argumento de Hegel parte de uma tese, construída ao longo da "Introdução" das Linhas fundamentais (Grundlinien, 
esp. §33) e, de resto, em toda sua obra madura, que afirma, sucintamente, que a cada momento do estado corresponde uma figura de liberdade contingente, cada qual suprassumida à medida que o direito, seu correlato autoconsciente, reconhece sua contingência e, portanto, a necessidade de sua superação. Ou seja, não é o caso de a posição kantiana ser simplesmente falsa, mas sim que é um momento, não o todo, do verdadeiro. Todavia, e aqui aparece a segunda razão para a distinção entre o momento da sociedade civil e o do estado constitucional, essa estritamente crítica. Hegel quer também notar que há uma contradição fundamental em Kant, uma hipocrisia fundamental (RUSSON, 2004, p. 150-154): se a moralidade demanda uma ação conforme a lei moral, entendida como mais alto valor, e isso significa que eu devo trazer meu eu natural à condição racional, então Kant implicitamente dá assentimento à tese de que a condição humana é de desarmonia em relação ao mais valor e explicitamente se opõe à condição humana em nome desse mais alto valor. Trata-se de uma reconciliação forçada entre espírito e natureza, forma de seu fantasma da liberdade. De modo explícito: "As raízes da moralidade estão na valorização da experiência humana, mas suas demandas explícitas são anti-humanas" (RUSSON, 2004, p. 151). Por mais que se veja mais Nietzsche do que Hegel nessa sentença, há um aspecto absolutamente hegeliano na crítica: a razão não existe de modo independente de agentes autoconscientes, no interior de um estado já constituído. A moralidade só compõe o mundo da experiência, caso ela se dê em relação à minha autodeterminação, ou seja, em relação a este estado.

E qual seria o momento da sociedade civil, que explicita a hipocrisia da moralidade kantiana, no contraste com o momento do estado constitucional, figura presente do espírito, no que concerne à relação entre direito e liberdade? Façamos um breve desvio, para responder à questão em sintonia com o último ponto da seção anterior. É inegável que, se seria possível dizer que em Kant há uma expiação legal ou uma hipocrisia fundamental, é impossível, de sua parte, deixar de considerar que, em Hegel, o resultado da reflexão acerca da liberdade e, por extensão, da 
relação entre teoria e prática política, também resulta em um primado do direito. Com efeito, toda sua filosofia, sob esse aspecto, conduz à afirmação, positivação do direito na forma da liberdade do estado. Contudo, e com isso voltaremos ao momento da sociedade civil, o que Hegel implica, ao fundamentar o estado constitucional, é que o direito é um princípio de organização. Nesse sentido, o direito é maior que todos os direitos particulares. Hegel dirá que a eticidade da sociedade civil burguesa é secundária em relação à eticidade do espírito do mundo (Grundlinien, §33). Ao juntar as duas partes do argumento, temos o seguinte: na sociedade civil, burguesa para Hegel, a organização social à qual o direito se interpõe como princípio de organização é regida pela forma do contrato, ou seja, o portador do primado do direito até Kant, segundo Hegel, é o direito privado. No momento do estado constitucional esse primado terá como portador o direito público. O limite da concepção de liberdade kantiana, seu fantasma, a razão de nela sobreviver uma hipocrisia fundamental, advém do fato de que não havia chegado à autoconsciência a contingência das relações de liberdade fundadas na sociedade civil burguesa.

Se Hegel desvela, nesse passo, o fantasma da liberdade kantiana já em sua posição da relação entre teoria e prática, caberá a Marx, também a partir da pressuposição hegeliana do complexo teoria/prática, desvelar o fantasma da liberdade em Hegel. Abordarei a questão a partir de a "Crítica da filosofia do direito de Hegel - Introdução", um texto publicado, nos Anais Franco-Alemães, em 1844"1 .

\footnotetext{
"O texto de Marx, Kritik der hegelschen rechtsphilosophie - Einleitung, será doravante referido por Introdução, seguido da paginação na edição brasileira. Cumpre lembrar a importante especificidade desse artigo, que segue, na edição brasileira, como apêndice ao Para a crítica da filosofia do direito de Hegel (Zur Kritik der hegelschen rechtsphilosophie), de 1843: escrito após o término da Crítica de 1843, o artigo define o afastamento da posição imediatamente anterior, ainda marcada pela tradição liberal-democrática, rumo a uma posição voltada à transformação radical, carreada pelo proletariado, sujeito capaz de "revolucionar desde os fundamentos" (Introdução, p. 157). Cf. a "Nota à segunda edição" e, em especial, a "Apresentação" da edição brasileira (ENDERLE, 2005).
} 


\section{Terceiro momento: Marx, Introdução}

O ponto de fuga da questão hegeliana, conforme aparece para Marx, poderia ser resumido do seguinte modo, se retomarmos os termos do problema até agora: quando se altera o sentido das relações de liberdade, pela alteração do portador do primado do direito, altera-se também o locus da questão do direito privado para o público, mas o cerne do problema de início, a relação teoria e prática no campo do dever, segundo a formulação por Kant, permanece o mesmo, qual seja, a pressuposição de uma relação com o estado. Não é outro o início da questão marxiana, se acompanharmos o argumento do texto.

Ainda que a posição de Marx acerca de vários problemas correlatos só ganhe forma final na primeira parte de $O$ Capital, de 1867 e, na verdade, isso se faça, em alguma medida, em um sentido contrário ao que aparece nesse texto de 1844 , argumento que esse texto, como outros do período de 1843 a 1845, é decisivo não apenas na concepção de seu método, como sublinhado por muitos comentadores, mas também para a relação que venho acompanhando, aquela que envolve teoria e prática, de um lado, e a crítica ao fantasma da liberdade, uma liberdade condicionada, pressuposta por uma forma abstrata, portanto, falsa reconciliação entre espírito e natureza, de outro.

Para tais propósitos, dois pontos são cruciais.

Em primeiro lugar, note-se que o fundamento da crítica de Marx é em mais de um sentido materialista. Por um lado, é materialista na esteira da crítica de Feuerbach em A essência do cristianismo (Das Wesen des Christentums, 1841), na medida em que ao expor a inversão na relação de causa e efeito que se dá entre o real e o ideal, Marx, de fato, acusa um veio místico na concepção de estado, veio místico que justamente havia recebido a atenção de Feuerbach, não em relação ao estado, mas à religião, e já era por ele diretamente ligada a Hegel. Nesse sentido, ao contestar a tese de que seja o estado que cria e sustém a sociedade civil, Marx constrói a tese de que são as pessoas reais, e os laços sociais que elas criam, que 
formam e sustém o estado. Mais do que isso, ao alegar que esses laços, desde a família até a sociedade civil, são o conteúdo da forma estatal, não apenas Marx está invertendo a perspectiva da relação entre forma e conteúdo, entre ideal e real, mas o faz seguindo a intuição de Feuerbach de que a condição humana, não sua abstração, é o fundamento do todo. Questionar a lógica de causa e efeito, ou ainda, dizer que analogamente ao caso da religião, não é o estado que cria indivíduos, mas esses que o fazem, e que, portanto, ele e ela nada são que entidades abstratas que vêm à frente por força dos laços inerentes à condição humana, abre como tarefa adicional explicar como ocorre essa mistificação ${ }^{12}$. Também na imposição dessa tarefa Marx segue o que Feuerbach entende como materialismo. Se fôssemos resumir o ponto, fazendo referência ao texto célebre do "Posfácio" da segunda edição de O Capital (1873), o elemento comum é o reconhecimento do mérito e o modo materialista - porque antimístico - de enfrentar Hegel:

A mistificação por que passa a dialética nas mãos de Hegel não o impediu de ser o primeiro a apresentar suas formais gerais de movimento, de maneira ampla e consciente. Em Hegel, a dialética está de cabeça para baixo. É necessário pô-la de cabeça para cima, a fim de descobrir a substância racional dentro do invólucro místico (MARX, 1985, p. 20-21).

Por outro lado, o fundamento da crítica marxiana é materialista em outro sentido, crítico a Feuerbach. Com efeito, se ambos entendem que, em Hegel, o espírito condiciona a existência, por meio de seu automovimento, e é justamente essa a pressuposição a ser criticada, Marx dirá que Feuerbach não completa a passagem ao materialismo porque não reconhece que a realidade concreta, que tem como origem o trabalho, mais do que a experiência dos indivíduos singulares, essa também uma

12 Em acréscimo à posição de Feuerbach, o sentido dado por Marx ao termo "mistificação", aqui, coincide com "logicismo" e "especulatividade", como acertadamente mostra Vaisman (2006, p. 336). Cf. o mesmo ponto em Hyppolite (1955, p. 127-131). 
abstração, é que tem como resultado as sucessivas formas da sociabilidade. De modo direto, mas sem nenhuma referência a Feuerbach, Marx dirá:

A tarefa imediata da filosofia, que está a serviço da história, é, depois de desmascarada a forma sagrada da autoalienação humana, desmascarar a autoalienação nas suas formas não sagradas. A crítica do céu transforma-se, assim, na crítica da terra, a crítica da religião, na crítica do direito, a crítica da teologia, na crítica da política (Introdução, p. 146).

Este ponto de afastamento de Marx em relação a Feuerbach não será encontrado explicitamente senão em outro texto do período, as célebres Teses sobre Feuerbach (Ad Feuerbach, 1845). A sexta tese diz:

Feuerbach converte a essência religiosa na essência humana. Porém a essência humana não é uma abstração inerente ao indivíduo singular. Em sua realidade efetiva, ela é o conjunto das relações sociais. Feuerbach, que não entra na crítica desta essência real efetiva, é consequentemente obrigado: 1. A fazer abstração do curso da história e a fixar o sentimento religioso para si, e a pressupor um indivíduo humano abstrato-isolado [...] (MARX, 1990, p. 33).

A sétima tese conclui: "É por isso que Feuerbach não vê que o 'sentimento religioso' é ele próprio um produto social e que o indivíduo abstrato que ele analisa pertence à mesma forma social determinada" (MARX, 1990, p. 34). Exatamente por isso, porque o materialismo, além de antimístico, é voltado ao concreto, Marx será levado não só a criticar Feuerbach, mas também a encontrar o seu próprio prumo para o problema. Outra passagem do mesmo "Posfácio" de O Capital, indicará uma concepção de método dialético que ele, paulatinamente, desenvolve desde sua crítica a Feuerbach.

Por sua fundamentação, meu método dialético não só difere do hegeliano, mas é também sua antítese direta. Para Hegel, o processo de pensamento, que ele, sob o nome de ideia, transforma 
em sujeito autônomo, é o demiurgo do real, real que constitui apenas sua manifestação externa. Para mim, pelo contrário, o ideal não é nada mais que o material, transposto e traduzido na cabeça do homem (MARX, 1985, p. 20).

Se perguntássemos não acerca das características desse método, mas acerca do que nele está implicado como um método propriamente materialista, reencontraríamos a crítica a Feuerbach, na décima tese: “O ponto de vista do antigo materialismo é a sociedade civil-burguesa; o ponto de vista do novo é a sociedade humana ou a humanidade social" (1990, p. 35).

Com isso, retornamos ao ponto de início da seção, para, então, destacar o segundo ponto crucial no texto. Se o ponto de vista deve ser o da humanidade social, o concreto de toda forma social determinada, portanto, o fundamento objetivo tanto da sociedade civil como do estado de direito, e se a teoria não é mais do que a idealização do material transposto da prática, se, portanto, o dever-ser implícito da teoria é não se alijar da prática, mais do que isso, realizar-se, então qual é, exatamente, o sujeito do processo? Se é possível concluir, até aqui - isto é, conforme os momentos do modelo de pensamento que aqui proponho -, que essa história é uma de usurpações, não no sentido trivial, mas propriamente, ou seja, que cada transição entre formas sociais oculta o fato de que é, a cada vez, a abstração das relações concretas que, por um lado, institucionaliza uma constituição política e, por outro lado, pela mistificação que então advém, invisibiliza a ausência de liberdade - aí, o fantasma - que está na base do ato constituinte, então, literalmente, o que fazer?

Nas partes finais da "Introdução", o que se vislumbra é uma teoria da revolução, mais propriamente uma revolução que se assenta na posição do proletariado. A distinção crítica na passagem é a que se faz entre uma revolução meramente política, entendida como parcial, e uma revolução radical, aquela que se articula a uma específica concepção da luta de classes (Introdução, p. 154). O argumento compreende dois passos. Em primeiro lugar, uma classe particular pode reivindicar domínio em nome 
dos interesses de todas as classes à medida que é reconhecida como representante universal da sociedade, o que exige que outra classe seja reconhecida como a do "escândalo universal", contraste que, ao opor libertação e opressão, abre espaço para a emancipação humana. Tal seria o sonho utópico da Alemanha, o de uma revolução meramente política, que mantém os alicerces da estrutura social, ao mesmo tempo que vê, sucessivamente, as classes se sucederem como representantes universais, "num movimento dramático" (Introdução, p. 155), dado que cada qual se vê não como classe particular, mas necessariamente, à medida que realiza uma necessidade social, como portadora da emancipação de toda a sociedade. Essa é a situação além do Reno (Introdução, 151). Todavia, Marx destaca, em segundo lugar, que a condição específica da Alemanha - resumida exemplarmente na sentença "onde a vida prática é tão desprovida de espírito quanto a vida espiritual é desprovida de prática" (Introdução, 156) - essa posição está vetada. Na Alemanha, a sociedade civil chega tarde, o que significa, nos termos do modelo de pensamento aqui proposto, que a consciência da contingência das relações de liberdade nela fundadas igualmente chega tarde, ou seja, as classes que a compõem vêem a si mesmas e se articulam não a partir de sua contraposição, mas a partir de sua constituição meramente formal, o que implica que suas reivindicações particulares sejam postas apenas a partir de seu "modesto egoísmo" (Introdução, 155). Nesse caso, argumenta Marx, a emancipação radical aparece como condição da emancipação parcial. Logo, o artífice da revolução não pode ser outro que aquele ausente da constituição da sociedade civil, aquele que não tem reivindicações parciais, mas uma reivindicação geral: a de ser incluído na humanidade social. Se as duas figuras do fantasma da liberdade são a troca, em termos da sociedade civil, e o próprio direito, em termos de estado constitucional, passo secundário que oculta e, portanto, reitera em termos de direito público o que já está contido como condição de possibilidade da igualdade no direito privado, a saber, a propriedade privada, então apenas o proletariado, o ente produzido pelo sistema político como aquele que nada possui, pode eman- 
cipar-se radicalmente. Mais do que isso, a expectativa de Marx, fundada em um diagnóstico do seu tempo presente, é que o proletariado alemão seja, efetivamente, o portador da humanidade social: "a emancipação do alemão é a emancipação do homem" (Introdução, 157). E se esse é o aspecto prático do problema, note-se que ele se faz articulado a um passo teórico: o deflagrador desse processo não é outro que a própria teoria, dado que é ela que, a cada momento, justifica, porque mistifica, a condição de usurpação fundamental, a saber, aquela que supõe que o estado sustém a sociedade civil e, por sua vez, essa sustém as relações sociais, sendo que Marx argumenta que essas relações são, ao contrário, o conteúdo daquelas formas. Logo, é da realização da filosofia que se trata.

Como se sabe, a expectativa se frustra. O que se vê, então, é um conjunto de modificações na obra de Marx, de resto já plena de idas e vindas, correções e inconsistências. Nesse contexto, reitera-se a pergunta, o que fazer? A proposta que apresento, seguindo uma intuição de Fausto (1987, p. 241), é que Marx concluirá, mas não nesse momento, que a cada vez, para cada forma social, há um sujeito, não da história, que já vimos que é a humanidade social, mas do próprio processo histórico. Ora, é a essa dinâmica que quero vincular o modelo de pensamento voltado ao fantasma da liberdade. Em Kant, esse era a constituição legal do estado. Hegel, ao revelar a contingência das relações de liberdade pressupostas por Kant e demonstrar que elas estão formalmente limitadas pela sociedade civil e que, portanto, elas deveriam ser suprassumidas na liberdade do estado, acusa o fantasma em Kant e eleva o próprio estado de direito a sujeito. No jovem Marx, a crítica ao formalismo dialético hegeliano o levará a encontrar as relações concretas - especialmente as que se dão na sociedade civil - como as doadoras dessa forma estatal pressuposta por Hegel e, portanto, revelará a usurpação da liberdade no sistema hegeliano. Entretanto, como sua crítica a Feuerbach indica, também tais relações são fantasmagóricas. Revelar o ponto de vista da sociedade civil-burguesa foi a tarefa do antigo materialismo, seu momento de verdade em relação à posição hegeliana. A falsidade desse ponto de vista 
deveria ser demonstrada ao se encontrar aquilo que, em sentido enfático, está pressuposto nessas relações. Dito de outro modo, se o sujeito real da história é a humanidade social, e ao menos como figura histórica o proletariado é seu portador, então quem é o usurpador, quem é o sujeito fantasmagórico que supostamente funda as relações de liberdade? Nesse momento, ainda não há resposta. Marx não encontrou a instituição que o carrega (constituição legal do estado, para Kant; estado de direito, para Hegel; sociedade civil-burguesa, para o Marx dos textos examinados). Mais à frente, seu nome será Capital. Contudo, se do lado de Marx essa compreensão significou uma alteração de ênfase, digamos cum grano salis, de uma teoria da revolução proletária para uma teoria do capital como totalidade ${ }^{13}$, o mesmo não se viu do lado de fora, por assim dizer. Nossa pauta é, ainda, a outra, a anterior, aquela que, em certa medida, já é fantasmagórica para o Marx tardio. Com efeito, por infindáveis reformulações e críticas recíprocas, o final do século XIX e todo o século XX se viram marcados pela articulação teoria e prática nos moldes de uma teoria e prática do processo revolucionário.

Aqui, voltamos a Adorno (2009, p. 193), voltamos a passagem. Cito novamente.

O fantasma da liberdade - que não deixa a razão se estiolar em face da presença de nenhuma prova de interdependência causal - é o fantasma de uma reconciliação entre espírito e natureza.

O ponto de chegada deste texto é a posição de Adorno face a Marx, ou mais precisamente, face a uma compreensão fantasmagórica da liberdade, porque restritiva, do marxismo ocidental, que se vê apoiada em uma compreensão mecânica da relação teoria e prática. A Dialética Negativa é, nesses termos, a resposta a esse fantasma.

13 Para uma apresentação do percurso teórico de Marx como correlato dos momentos de sua crítica a Hegel, Cf. Arthur (2000, passim). 


\section{Referências}

ADORNO, Theodor W. Dialética negativa. Tradução: Marco António Casanova; Revisão técnica: Eduardo Soares Neves Silva. Rio de Janeiro: Jorge Zahar, 2009. ALMEIDA, Guido A. Introdução. In: KANT, Immanuel. Fundamentação da metafísica dos costumes. Tradução, introdução e notas: Guido de Almeida. São Paulo: Discurso: Barcarolla, 2009. p. 11-55.

ARTHUR, Christopher J. From the Critique of Hegel to the Critique of Capital. In: BURNS, Tony; FRASE, Ian (ed.). The Hegel-Marx connection. London: Macmillan Press, 2000. p. 105-130.

BECK, Lewis W. Das Faktum der Vernunft: zur Rechtfertigungsproblematik in der Ethik. Kant-Studien, Mainz, n. 52, p. 271-282, 1961.

BOBBIO, Norberto. Direito e estado no pensamento de Emanuel Kant. Tradução: Alfredo Fait. Brasília: Editora Universidade de Brasília, 1984.

BOBBIO, Norberto. Estudos sobre Hegel. Direito, sociedade civil, estado. Tradução: Luís Sérgio Henriques e Carlos Nelson Coutinho. São Paulo: Brasiliense, 1989.

ENDERLE, Rubens. Apresentação. In: MARX, Karl. Crítica da filosofia do direito de Hegel, 1843. 2. ed. rev. Tradução: Rubens Enderle e Leonardo de Deus. Supervisão e notas: Marcelo Backes. São Paulo: Boitempo, 2010. p. 11-25 FAUSTO, Ruy. Marx: lógica e política. Tomo I. São Paulo: Brasiliense, 1987.

GEIGER, Ido. The founding act of modern ethical life: Hegel's Critique of Kant's Moral and Political Philosophy. Stanford, CA: Stanford University Press, 2007. HEGEL, Georg W. F. Grundlinien der Philosophie des Rechts oder Naturrecht und Staatswissenschaft im Grundrisse. In: HOFFMEISTER, Johannes (ed.). Hauptwerke in sechs Bänden. Darmstadt: WBG, 1999. v. 5.

HÖFFE, Otfried. Immanuel Kant. Tradução: Christian Viktor Hamm e Valério Rohden. São Paulo: Martins Fontes, 2005.

HYPPOLITE, Jean. La conception hégélienne de l'État et sa critique par Karl Marx. In: Études sur Marx et Hegel. Paris: Librairie Marcel Rivière et Cie, 1955. p. 120-141.

KANT, Immanuel. Metaphysischen Anfangsgründe der Rechtslehre. WEISCHEDEL, Wilhelm (org.). Werke in Zehn Bänden. Darmstadt: WBG, 1983. v. 7, t. 2. p. 309-499. 
KANT, Immanuel. Über den Gemeinspruch: Das mag in der Theorie richtig sein, taugt aber nicht für die Praxis. In: WEISCHEDEL, Wilhelm (ed.). Werke in Zehn Bänden. Darmstadt: WBG, 1983. v. 9. p. 127-172.

KANT, Immanuel. Crítica da razão pura. 3. ed. Tradução: Valério Rohden e Udo Baldur Moosburger. São Paulo: Nova Cultural, 1987. v. 1.

KANT, Immanuel. Crítica da razão pura. Tradução: Valério Rohden e Udo Baldur Moosburger. São Paulo: Nova Cultural, 1988. v. 2.

MARX, Karl. Teses sobre Feuerbach. In: LABICA, Georges. As "Teses sobre Feuerbach" de Karl Marx. Tradução: Arnaldo Marques. Revisão técnica: João Quartim de Morais. Rio de Janeiro: Jorge Zahar, 1990.

MARX, Karl. Crítica da filosofia do direito de Hegel, 1843. 2. ed. rev. Tradução: Rubens Enderle e Leonardo de Deus. Supervisão e notas: Marcelo Backes. São Paulo: Boitempo, 2010.

MARX, Karl. O Capital: crítica da economia política. 2. ed. Apresentação: Jacob Gorender. Coordenação e revisão: Paul Singer. Tradução: Régis Barbosa e

Flávio R. Kothe. São Paulo: Nova Cultural, 1985. v. 1.

RIEDEL, Manfred. Theorie und Praxis im Denken Hegels: Interpretationen zu den Grundstellungen der neuzeitlichen Subjektivität. Frankfurt am Main: Ullstein, 1976.

ROHDEN, Valério. Interesse da razão e liberdade. São Paulo: Ática, 1981.

RUSSON, John. Reading Hegel's Phenomenology. Bloomington: Indiana University Press, 2004.

SILVA, Eduardo S. Neves. Coerência em suspensão: Adorno e os modelos de pensamento. Artefilosofia, Ouro Preto, n. 7, p. 55-72, 2009.

SILVA, Eduardo S. Neves. Filosofia e arte em Theodor W. Adorno: a categoria de constelação. 2006. Tese (Doutorado em Flosofia) - Universidade Federal de Minas Gerais, Belo Horizonte, 2006.

TERRA, Ricardo. É possível defender a legalidade e ter entusiasmo pela revolução?. In: Passagens: estudos sobre a filosofia de Kant. Rio de Janeiro: Editora UFRJ, 2003. p. 101-129.

TREPTOW, Elmar. Theorie und Praxis bei Hegel und den Junghegelianern. 1971. Tese (Tese de Habilitação em Filosofia) - Ludwig-Maximilians-Universität München, Alemanha, 1971. 
VAISMAN, Ester. Marx e a Filosofia: elementos para a discussão ainda necessária. Nova economia, Belo Horizonte, v. 18, n. 2, p. 327-341, 2006.

ZINGANO, Marco A. Razão e história em Kant. São Paulo: Brasiliense, 1989. 